\title{
Common Property and Power: Insights from a Spatial Analysis of Historical and Contemporary Pasture Boundaries among Pastoralists in Central Tibet
}

\author{
Kenneth M. Bauer \\ University of Vermont
}

\section{Introduction}

Significant political and economic changes occurred in Tibetan pastoral areas after the 1950s: Tibet's political economy was transformed from a feudal theocracy, to collectivized communes (19671980), through to the contemporary hybrid of capitalism and socialism (1981-present). These sweeping changes prompt this investigation into the dynamics of common property in relation to political developments. Given the marginality of Tibet's environment, it is tempting initially to hypothesize that resource use and property regimes were determined by natural conditions, which inherently limited alternatives, rather than political circumstances. Following this line of thinking, one would posit that ecological factors like climate change and bio-productivity were determinative of Tibetan herders' adaptive choices and arrangements for sharing resources. Moreover, one would presume stability in the location of pasture boundaries and venture that opportunities of resource access have not changed significantly, despite tumultuous changes in Tibet's governance. Instead, this article documents how territorial boundaries and patterns of resource availability in the Porong region have, in fact, been dynamic and are more complex than common property theorists have generally insinuated. Having compiled and analyzed data from historical archives, field observations, interviews, and satellite images, this article argues that common property regimes are contingent on political processes and that state entities have played a central and abiding role in the delineation of pastures boundaries, access to rangeland resources, and the mediation of conflict.

\section{Study Site and Methods}

This research was conducted between 2002 and 2004 in the Tibet Autonomous Region (PRC). ${ }^{1}$ For this article, I draw primarily upon data from Porong Township (Nyelam County, Shigatse Prefecture). Historically, the Porong region was administered as an autonomous principality. ${ }^{2}$ Porong (T., pong rong) was governed by the Jewön (T., rje dpon), whose family ruled the area for centuries and controlled a large number of nomad serfs (Diemberger 2002). ${ }^{3}$ Today, Porong Township is

\footnotetext{
$1 \quad$ Winning paper, Anthropology and Environment section, American Anthropological Association Junior Scholar Award, 2007. The author would like to gratefully acknowledge support from the US National Science Foundation, the Wenner Gren Foundation, and the Clarendon Fund Bursary (Univ. of Oxford), and the comments of two referees. Address: Community Development and Applied Economics Department, University of Vermont, VT 05405, USA. ken.bauer "at" uvm.edu or kenneth.bauer "at" linacre.oxford.ac.uk.

2 Porong principality was located in the district (T., rdzong) of Shekar (T., shel dkar); it encompassed parts of the modern day counties of Dingri, Nyelam, Ngamring, and Kyirong in the TAR. Until China's assimilation of Tibet, the relationship in Porong between the community, its territory, and its leadership was shaped by a semi-autonomous political system sanctioned by the central government of Lhasa (Diemberger 2002). Since the 15th century, the cultural identity of the people of Porong (Porong-wa) has been centered on a group of monasteries belonging to the Bodongpa, a small sect of Tibetan Buddhism, founded by one of Tibet's pre-eminent scholars, Bodong Chokle Namgyal (T., bo dong phyogs las rnam rgyal, 1375-1451). Chhogle Namgyal is known as a contemporary teacher of the first Dalai Lama and the first Panchen Lama (c.f. Diemberger et al 1997, Ramble 2002).

3 Tibetan terms are transliterated using the Wylie system. This system of transcribing Tibetan was devised by Professor Turrell Wylie (1959). Any Tibetan language Romanization scheme is faced with a dilemma: should it seek to accurately reproduce the sounds of spoken Tibetan or the spelling of written Tibetan? Tibetan orthography became fixed in the 11th century while pronunciation continued to evolve. The Wylie system is not intended to help in the correct pronouncing of Tibetan. It was designed to type Tibetan language using a normal English keyboard. It has subsequently become a standard transliteration scheme in Tibetan studies, especially in the United States. In this article, Tibetan terms will be identified inside brackets, i.e., "(T., <Wylie spelling of term >)".
} 
adjacent to the China-Nepal border approximately 700 kilometers west of Lhasa, the capital of the TAR (Figure 1). ${ }^{4}$
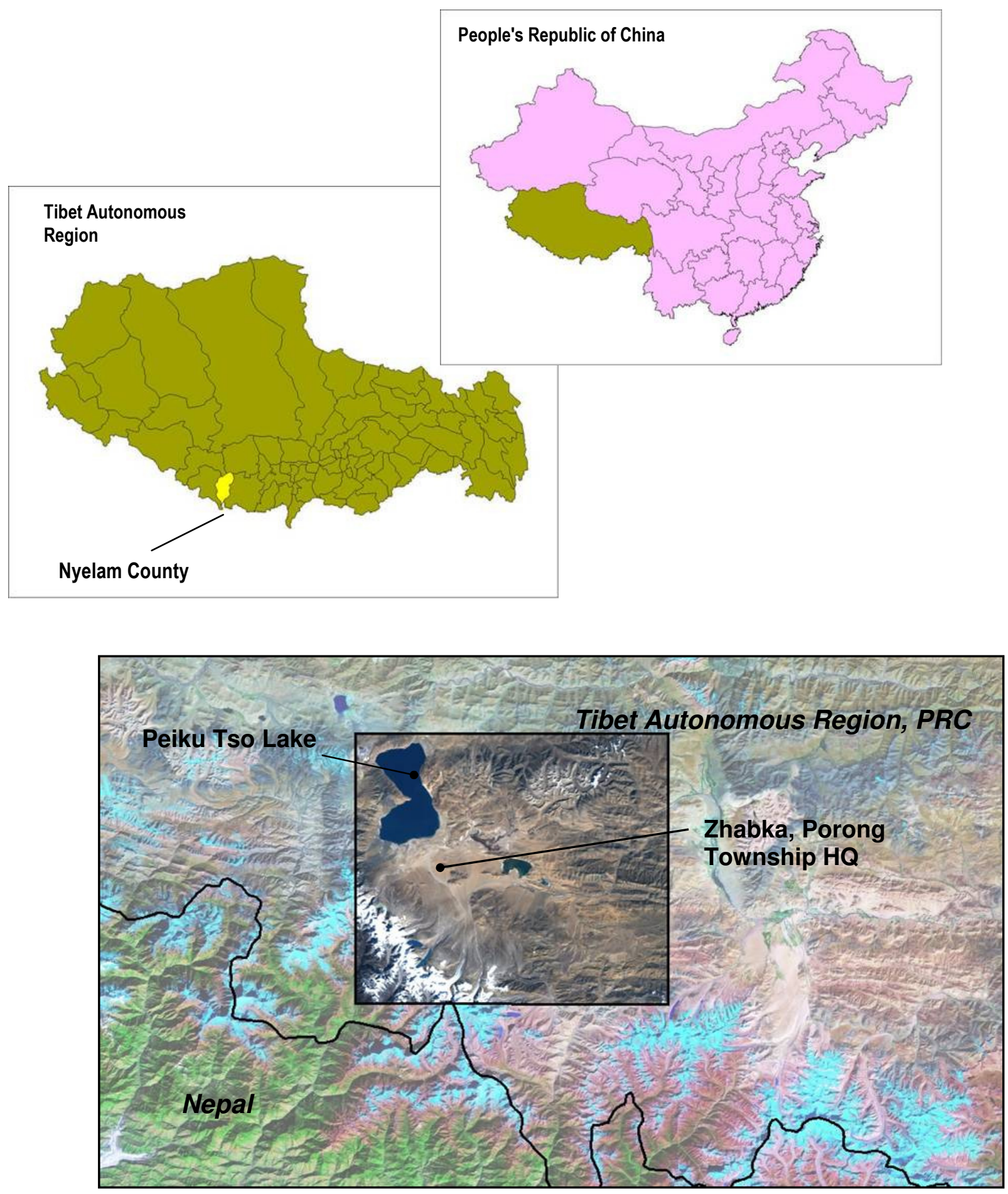

Figure 1: Location of Porong

Mandarin terms are transliterated using the pinyin system and identified inside brackets, i.e., "(M., < pinyin spelling >)".

$4 \quad$ Porong Township's location: $28^{\circ} 21^{\prime} \mathrm{N}, 85^{\circ} 47^{\prime} \mathrm{E}$.

Journal of Political Ecology

Vol. 13, 2006 
The township is situated just north of the Himalayas that form the boundary between China and Nepal; Mt. Shishapangma $(8,013 \mathrm{~m})$, the world's fourteenth highest peak, falls within the borders of the basin, which drains into Peiku Tso Lake. ${ }^{5}$ In 2003, Porong comprised nine administrative villages containing some 380 households, with a total population of just over 2,000 people; average per capita income was US \$228 (Nyelam AHB 2003). Porong Township is the largest animal husbandry production area in Nyelam County and comprises a third of its land area. ${ }^{6}$

It is important to make explicit the conditions under which data collection occurred and the limitations associated with this research. First, my research permit made it impossible to stay at-length anywhere outside of Lhasa. When I was in the field, I was required to be accompanied by researchers from the Tibet Academy of Social Sciences (TASS): these TASS faculty members had limited time for rural field trips and were, at times, constraining factors in the kinds of questions I could ask of my interlocutors. Due to permit and budget constraints, I was also forced to make strategic decisions about whom I would interview and how I would spend my time most productively.

In Porong, I employed local assistants who helped locate toponyms and boundary points as well as facilitated communication with community members. I interviewed individuals from families in each of Porong's nine 'natural villages' (M., cun). I obtained my data about land use and pasture boundaries in Porong almost exclusively from interviews with two focus groups: herders and village leaders/headmen. These individuals were drawn from many families and settlements within Porong. The headmen were typically older and of a certain social status; most had been central participants in the political process and administration of Porong's communities during the past 50 years. Through a variety of roles - commune accountant, village Party secretary, lineage (T., rgyud) headman, etc. they had been, and still are, responsible for most of the practical, day-to-day decisions regarding land management and pasture boundaries in Porong. For years, these men have acted as 'land wardens,' dealing with boundary conflicts and mediating resolutions through traditional social institutions or government channels. I spoke with these men at length, using structured and semi-structured interviews as well as informally asking questions and observing them in the field. In addition, I interviewed in-depth most of Porong Township's government staff as well as representatives of the Animal Husbandry Bureau and Grassland Stations at the county (Nyelam), prefectural (Shigatse), and regional (Lhasa) levels.

In defining the study site and parameters of this research, it is critical not to essentialize the Porong 'community' by assuming that decisions about land (e.g., boundaries) and resources (e.g., access to pastures) have been made without dissension or resistance. One must be careful not to drain society of differences in purpose, both in the past and the present. Although I do make some generalizations about the nature and practices of common property in what follows, I also acknowledge the impact on resource use that individuals' lassitude, entrepreneurship, native intelligence, curiosity, etc. may have had on land use during the period under consideration. Nor do I wish to assume that knowledge concerning pastoral production is held only by the men who make decisions about herding animals and settling conflicts. Limited by the time constraints placed on me by travel permits and the costs associated with fielding assigned research assistants (who often had their own ideas about 'worthy' interviewees), I had few detailed conversations with women, even though they play critical roles in pastoral production - as dairy processors, weavers, fuel collectors, and sometimes herders - and even though the decisions they make do impact land use. Moreover, I met only a few members of the lower strata like blacksmiths, whose houses and lives stand separate from the main village. We cannot dismiss the fact that forms of knowledge are not homogeneous or egalitarian: differences will be found along the lines of gender, age, class, occupation, etc. Informed by a wider pool of individuals from Porong, this account of resource use and property relations would, no doubt, have been richer. But the opportunity to conduct research in Tibet is rare, and the chance to work with baseline historical material such as the Porong boundary survey rarer still. So, I proceed, with the recognition of both the value and the limits of this endeavor.

5 According to Nyelam County government documents (Nyelam AHB 2003), the average altitude of Porong is 4300-4600 meters, average temperature is 0.70 Celsius, and annual rainfall ranges between 200-236 $\mathrm{mm}$.

6 Local cadres reported in 2003 that the total numbers of animals was 54,065 (6,643 yak, 37,789 sheep, 9,157 goats, 476 horses) (Nyelam AHB 2003).

7 Society is never a completely 'integrated entity' since in any community there exist forms of protest in conflict with the current hierarchical structure. We must therefore be critical of assumption that values - in this case, those concerning land management - in a given society converge into some unitary system. Such a stance overestimates the homogeneity of social values and fails to address the contrasting subjectivities and perceptions of status found among different segments of society (c.f. Arce and Long 2000). 
Even though historical records like the 1884 Porong Boundary Text invite comparisons between field observations and archival evidence as a path to detecting long-term patterns in land use and environmental productivity, this effort has both the advantages and disadvantages of setting out in relatively uncharted research terrain. ${ }^{8}$ With these lacunae in mind, I turn now to a description of the process by which a $19^{\text {th }}$ century text was made to speak to the present - in the form of maps depicting resource use and pasture boundaries in 1884 and 2004. The next section outlines the hermeneutical procedure I followed in interpreting the Porong Boundary survey to define landscape elements, to construct patterns of similarity and difference between past and present uses, and to link information at different scales (hand-drawn maps vs. satellite images) presented in different formats (e.g., text, tabular data, remote sensing, etc).

\section{The Porong Boundary Survey}

Boundary surveys such as the document with which I worked were once common throughout the Tibetan-speaking world. ${ }^{9}$ The text which formed the core of this mapping effort was smuggled out of Tibet in the early 1960s, carried by pack animals and on foot over the Himalaya by members of Porong's erstwhile elite, who had gone into exile in Nepal. This act made available a kind of document that is rare to find inside Tibet at this juncture for three reasons: (1) village council and monastery texts were burned and destroyed during the Cultural Revolution; (2) the number of religious texts that were secreted out of Tibet far outnumbers other kinds of documents such as government records; and (3) pre-1950s documents pertaining to the government in Tibet have been systematically seized by the current government (and are presumably kept in archives in Lhasa and Beijing). As such, the Porong Boundary Survey represents a previously untapped resource in studies of land use among Tibet's highaltitude pastoralists. Specifically, this case study captures critical changes and continuities in common property and resource use, since the 1884 to 2004 period bookends significant transitions in Tibet's governance - from feudalism to socialism.

The Porong Boundary Survey lists the common property boundaries for one administrative unit (T., tsho) in this principality. ${ }^{10}$ The twenty units named in the Porong Boundary Text belonged to an administrative entity known as pal byang tsho, the boundaries of which are coterminous with today's Porong Township, headquartered at Zhabka (T., zhabs ka). In the text, boundaries are delineated by recognizable physical landmarks like high ridges and river confluences as well as by manmade markers such as livestock corrals and cairns. The abodes of place deities - often visible as outstanding features in the landscape - also double as boundary markers. ${ }^{11}$ With its detailed lists of toponyms and identifiable landscape features, the Porong Boundary Text provides a unique lens for looking at boundaries over time and generates insights about the similarities and differences in historical and contemporary common property regimes. Specifically, the text allowed me to: (1) locate and accurately map pasture boundaries as they were delineated in 1884; (2) catalogue and georeference hundreds of resource use points; and (3) compare pasture boundaries in two periods. The cumulative result of my efforts was a gazetteer of the Porong region $\left(4034 \mathrm{~km}^{2}\right)$ which contained over 1400 place names, of which more than 500 points were geo-referenced using a GPS unit and remote sensing technologies.

$8 \quad$ With the exception of work Karl Ryavec's $(1998,2001)$ spatial analyses of census data from the Iron Tiger year (1838), I know of no other attempts to systematically explore historical data compiled by the various bureaucracies of indigenous Tibetan polities using GIS technologies. Others have constructed GIS models of Central Asian pastoralism, e.g., in Afghanistan (Casimir et al 1992) and Mongolia (Rasmussen et al 1999, Christensen et al 1998, Christensen et al 1999).

$9 \quad$ Ramble (1995:88) writes: "Disputes between communities over usufruct rights to pasture and forest land are extremely common, and peaceful relations between neighboring villages depend to a large extent on the existence of texts that delineate frontiers by means of a meticulous description of the territory in question." In a parallel example, the existence of codified pastoral tenure arrangements in Mongolia dates back to the 13th century when numerous Mongol tribes, occupying territories known as aimag, were unified under Chinggis Khan (Sneath 2000).

10 There are several possible explanations for this administrative initiative. For example, deaths or a succession in the Jewön's family lineage as well as restructuring at higher levels of the Lhasa government could have affected the regional distribution of estates and the allocation of resources within Porong (c.f. Goldstein 1973 on the circulation of estates in feudal Tibet). The demands of war also drove administrative reorganizations, particularly for the purpose of increasing revenues through tributes, conscripting soldiers, and seizing pack animals used in martial campaigns.

11 For more on sacred geography among Tibetan speakers, see Schlee (1989), Kind (2002), Diemberger (1994, 1998), Ramble (1997, 1999), Huber (1999). 
The Porong Boundary Survey is written in 'u med, one of several cursive scripts into which the written Tibetan language can be rendered. At the outset, the document was transcribed into Roman letters using the Wylie system. ${ }^{12}$ The Wylie transliteration of the text allowed me to enter place names into standard word-processing and spreadsheet programs, a necessary precursor to building a gazetteer and constructing a spatial database.

According to the first line of this document, the text was written on, "The twentieth day of sixth month in the Wood Monkey year at an auspicious time." Official records of the Tibetan government typically began in this way, with due consideration for propitious moments in the lunar and astrological calendar. ${ }^{13}$ Tibetans divide calendrical time into 60 year cycles, with each year given a unique name based on combining astrologically-assigned animals and elements. ${ }^{14}$ In the Tibetan system, the most recent Wood Monkey year was 2004. Based on my informants' deductions, then, this text was recorded in $1884 .{ }^{15}$ However, many of the boundaries and toponyms used to delineate pasture areas are likely more than 300 years old. ${ }^{16}$

The text itself follows a template that is recognizable and becomes predictable with practice. First, the name of a landscape architectural element (such as an encampment or settlement) is written in red ink. The settlement name is then followed by a long list of points that mark the location of boundaries based on landscape features and toponyms. A typical sentence reads,

The boundaries of Phumar: from the shady side of ru rgyu corral to the east peak of 'khyag lung. Then stop at ser po o log corral. Then from the east peak directly to 'chang mo'i gong corral. Go from the shady side to the rock called skye zer. Then from lha mo na kha'i mjug grassland follow the stream of mdo ra. Stop at the gorge called gad 'dzul shar ma. Then follow the phu smar stream. (lines 3-8)

As seen in this passage, a variety of information besides toponyms are added to these boundary directions, including cardinal directions, aspect, and environmental conditions (e.g., shady, cold, etc).

Place names, or toponyms, comprise a distinct semantic domain in the lexicons of all known languages. Formal properties of place name systems, together with their spatial correlates and etymological histories, have long been objects of anthropological inquiry. ${ }^{17}$ Keith Basso (1996:7) writes, "Place names serve humankind as durable symbols of distant events and as indispensable aids for remembering and imagining them." In the Tibetan context, place names have shown themselves to be good anchors from which to hang an analysis of land use and property regimes over time. The recurrence and long-held practice of using place names in this landscape means that the Porong

12 See Note 3 for a description of the Wylie system of transliteration.

13 Crook and Osmaston (1994) discuss the importance of auspiciousness in Tibetan time-keeping.

14 The twelve years in the Tibetan astrological cycle are named after animals: Rat, Cow, Tiger, Hare, Dragon, Snake, Horse, Sheep, Monkey, Bird, Dog and Pig. Each year in the astrological cycle is also assigned one of five elements: Wood, Fire, Earth, Metal and Water. As such, each year in a 60-year cycle is uniquely identified by the combination of animal plus element. In this case, the Porong Boundary Survey was written in a "Wood Monkey" year.

15 The text is signed and sealed by two men: the local feudal ruler, the Jewön (T., rje dpon) of Porong named Lhakyab (T., lha skyabs) and Lobsang Sherab (T., blob sang shes rab), an official serving the Panchen Lama's monastery, Tashilhunpo, in the regional headquarters of Lhatse. The estate rights of the Porong Jewön were recognized in a set of decrees issued by the Lhasa government. I reviewed one such historical document, an edict from the government of the sixth Dalai Lama, which settled a conflict between the principalities of Porong and Kyirong. In the document, the government states that, because the Porong-wa had provided soldiers and served the government faithfully in its war against Ladakh, they were entitled to the lands being contested by these two regions. While the Porong Boundary Text is signed by a representative of the Panchen Lama, the Porong principality was considered to be part of the Dalai Lama's Lhasa-based theocracy due to the high standing of Porong's major monastery, Pema Chöding.

16 Informants vouched that the Porong Boundary Text is a copy of older documents at least 300 years old. Their reasoning: according to historical records, the rje dpon arrived in Porong and established his encampment at 'bra chen approximately 340 years ago. At that time the name of this place, ngo ron, was changed to 'bra chen (which means 'large tent'). Nevertheless, the toponym, ngo ron is used to identify this location in the Porong Boundary Survey. Other toponyms can likewise be dated as being more than three centuries old.

17 Early in the 20th century, Edward Sapir (1912) argued that Native American vocabularies provided valuable insight into their conceptions of the environment. Likewise, Franz Boas (1934) asserted that one of the most profitable ways to explore the 'mental life' of Native American was to investigate their geographical nomenclatures. 
Boundary Text is likely to have borne close resemblance to pastoralists' actual practices since it shares such a close geographical understanding of this region's rivers, rocks, ridges, and paths.

By understanding the meaning of Tibetan toponyms, we can cast our evidential net wider, using language as another way of triangulating the information being reported here about a landscape. Place names can offer evidence of change in the landscape in terms of appearance and function. Localities undergo physical changes and no longer conform to the way their names describe them; pastures that once gave life to species of plants that grew under moist conditions, may in the present have vanished or persist only in stunted form (Basso 1996). Such was the case in Porong, where the past (in the form of the text) revealed that its rangelands were once more productive. There were many occasions during fieldwork when we set out to find a spring or a pasture named in the text, only to find faint traces of a once lush wetland and now-abandoned corrals. Frequently we traced the location of a pasture named after productive grass species (e.g., so-called 'Giant Kobresia bogs,' after the species Kobresia schoenoides, or highly-valued forage species such as Pennisetum flaccidum) only to find desiccated plains filled with the poisonous species Atragalus monbeigii. In this case, evidence drawn from the past points to major shifts in local climatic patterns, thus allowing inferences to be drawn about how - and possibly why - the environment differed in key respects between periods.

Besides delineating boundaries, the text also prescribes land use by regulating season of use, rights of access by outsiders, types of animals, etc. For example, in a passage that follows the one cited above, the feudal ruler of Porong dictates,

[This is] the classification of animals for these pastures. Yak can graze summer and winter. During winter, yaks stay at $r u$ gyu corral. In the summer yaks stay at thang la corral. During autumn yaks stay at spyang khu nyal sar corral for ten days. During autumn sheep and goats stay to the east of here. (lines 16-18)

Thus, the text provides information not only about boundaries but also about the seasonality of land use, herd structure, resource values, and access rights.

A wide range of scholars, from semioticians and political scientists to archaeologists and social anthropologists, have illustrated the ways in which texts can be read as cultural histories. Texts are written under certain material conditions and are embedded within social and ideological systems: as such, they should be understood in the context of their production and interpretation. Texts have served a variety of purposes in Tibetan culture, none more prominent than the propagation of scripture. In Tibet, religious texts themselves are considered sacred objects - not only for the teachings they contain but also as physical manifestations of transcendent wisdom. ${ }^{18}$ But texts have also served managerial and coercive purposes in Tibet, as the Porong Boundary Survey attests in its legitimation of social hierarchies and in its governance of lawful relations concerning resource use and access. In this sense, texts such as this one can be interpreted as contemporaneous with state technologies of power (c.f. Foucault 1972, 1980; Hodder 2000). Territorial concepts imply the exercise of power so there is an organic connection between surveillance and the act of mapping (c.f. Watts 1992). Estate holders which, in the Tibetan case, included noble families, monasteries, and certain government offices - had an obvious incentive to initiate land surveys. In order to create taxable units around which the extraction of goods from subject populations could be organized, Porong's rulers created taxable units based on territories. In this sense, boundary making and surveying activities helped elites capture surplus wealth.

Still, it is necessary to advise against too 'easy' a reading of the boundary text. There is always some dichotomy between written policy and embodied practice in the observance of rules. Government records such as this text may have represented 'ideal' and officially sanctioned interpretations of boundaries and land use. The question is whether the boundaries that are recorded in this feudal record were known and observed by shepherds in their day-to-day and seasonal movements. Here I assume that the social stress of not heeding law, and the penalties brought against offenders who did not comply with this legal text, was incentive enough for herders to follow boundaries and respect resource regulations. Breaking these laws in a marginal and risky environment would likely be a nonadaptive choice, both in terms of fraying social relations and exposing one's household to catastrophic loss.

18 For example, when Tibetan pilgrims visit monasteries - particularly those known for their collections of texts - they will often circumambulate the library and bow before the religious tomes. Likewise, in many Tibetan communities, religious ceremonies around the New Year (T., lo sar) and planting season include the ritual carrying of texts around the village as a means of protection against bad fortune. 


\section{Participatory Mapping in the Tibetan Context}

This section describes the field techniques used to locate points listed in the Porong Boundary Survey as well as contemporary resource use points. On any given day in the field, my assistants and I proceeded first to ridgelines, passes, or other vista points to get the lay of the land and to strategize the routes to be followed. When a point named in the boundary text was found, a GPS reading was taken; contemporary livestock corrals, boundaries, fences, etc. were similarly located and recorded. Local informant(s) would then relate how past and present boundaries converged or diverged, and what kinds of animals were permitted to use a given area during a particular season. Notes and pictures were taken and the environs were roughly sketched. The GPS points recorded in the field provided the latitude and longitude coordinates that were needed to tie the Porong Text to real world locations. These points would eventually become vertices in digitized polygons that represent zones of land use, administration, tenure type, etc. The amalgamation of GPS points, together with interview notes, would allow a transformation of words into a set of maps that could be manipulated and classified using GIS applications.

The GPS points were augmented with hand-drawn, participatory maps made by local pastoralists. The process known in development circles as 'participatory mapping' entails community members working individually and in groups to construct maps which illustrate landscape features and pasture boundaries in their vicinity. ${ }^{19}$ The maps which my informants drew - on paper, in the dirt, and even in the air - were a key resource in understanding Porong's rangeland boundaries and their management system. Thus, it is vital to not only reconstruct the physical and social setting in which these maps were produced in Porong, but also to review the literature that is critical of the effects that making maps may have on the relationship between researcher and interlocutor as well as the significance of the information that maps communicate (c.f. Harley 1988).

In Porong, these mapmaking exercises were collaborative efforts, with several different people wielding colored pens and markers. At the beginning of each mapmaking project, participants were asked to draw the features of the landscape that they considered important and to illustrate (through words, lines, and symbols) their own uses of rangelands. Beyond asking these local cartographers to draw pasture boundaries, the mapping process was left deliberately open. The most common elements informants drew were ridges and mountains, rivers and bodies of water, open plains and grasslands, together with architectural features such as corrals and settlements. In carrying out these participatory mapping exercises, the objective was to give community members a chance to generate a vision of their particular production systems, according to their own cultural idioms and conceptions of land use. The resultant maps sometimes covered only small areas immediately adjacent to a village and other times reached the outer bounds of the entire township. The participatory maps created by Porong pastoralists were windows onto indigenous production techniques, the presence/absence of key resources (e.g., winter and lambing pastures, water springs, salt licks), and a means of depicting the relationships between administrative units and natural resource use boundaries. These locally-generated maps produced insights not only into how community members view and use their natural resources, but also provided a way to cross-check information obtained by remote sensing.

Maps as we have come to 'read' them - as portable graphic representations of the physical landscape - have only a short history in Tibet. Toni Huber (1999:60) writes:

... instead most Tibetans have relied heavily on oral and written textual maps or guides to navigate and interpret particular landscapes. These forms are much more intensive and immediate ways of relating to landscapes and places, as they can simultaneously invoke history, myth, cosmology, theories of substance, place, and person, social relations besides just geography and topography.

Yet, time and again, I have observed among the Tibetan pastoralists with whom I have worked an acute spatial sense. They latched quickly onto satellite images, and their maps of the

19 Participatory mapping can encompass a range of techniques, from roughly sketched maps to more technical efforts employing Geographic Information Systems (GIS) and remote sensing (Chapin et al 2005). The terminology to describe "participatory mapping" is diverse: "indigenous mapping" (Chapin et al 2005), "participatory land use mapping" (Chambers 1997, Brown and Hutchinson 2000), "participatory resource mapping" (Mbile et al 2003), "community mapping" (Bennagen and Royo 2000, Eghenter 2000, Fox 2002), "community-based mapping" (Flavelle 2002), "ethno-cartography" (Gonzalez et al. 1995), "counter-mapping" (Peluso 1995, Kosek 1998, Hodgson and Schroeder 2002). 
landscape were consistently drawn from a bird's eye view. While in some cultural contexts, Western cartographic concepts like the cardinal directions are exotic, orienting to north, south, east, and west is a long-established geographical principle in the Tibetan-speaking world. ${ }^{20}$

It is interesting to note that visualization exercises and mapmaking are germane to Tibetan culture and consciousness, particularly in relation to religious practices. Many meditation exercises in the Tibetan Buddhism entail complex three-dimensional visualizations of buildings and landscapes. ${ }^{21}$ In both secular and religious traditions of painting in Tibet, artists have attempted to render spatial relations in their depictions of landscapes. For example, paintings of the life stories of saints are often depicted in complex landscapes as a way of situating these holy men's travels and deeds. As such, graphic representations of landscapes (T., shing kham) have a long tradition in Tibet, even though they are most often used to represent other possible world-systems or Buddha-fields, cosmograms, and paradisical sketches of alternative realities. In virtually all cases these works are not maps that Tibetans could use to negotiate their own countryside. There are a few $19^{\text {th }}$ and $20^{\text {th }}$ century examples of maps (T., sab tra), literally 'variegated countryside,' but even these cartographic exercises in representing landscapes retained a unique Tibetan system of projection and spatial reference (Huber 1999).

Nevertheless, the nomadic sense of land is exceedingly topography-wise. The location of mountains, passes, ravines, good stands of grass, caves, rivers, springs, swamps, and qualities of the soil are all closely observed and recited. Through their criss-cross patterns of daily walking or riding after animals, the herdsmen intimately know their landscape (generally the environs of their natural village and the routes of egress). Theirs is not an academic interest in tallying toponyms but a practical concern with the finding of stray livestock, taking the shortest route to campsites, or the most secure passage for trade ventures. Because of their close knowledge of their landscape, I found that Porong's nomads drew very passable maps and, given points of reference, could pinpoint topographical features if shown maps of their 'home turf.' Still, despite these potentialities, it is important to address some of the critiques of participatory mapping.

\section{Critiques of Participatory Mapping}

The main critiques of participatory mapping - and its incorporation into GIS - are epistemological and political. The first set of objections concerns whether or not 'indigenous knowledge' can be integrated into western cartographic representations. ${ }^{22}$ Let us consider this critique in relation to pastoralism, a form of production that is far from uniform and varies alongside soils and vegetation. On the Tibetan Plateau, 'local knowledge' truly is context-dependent and communityspecific by virtue of the fact that encampments are often separated by substantial zones of inhospitable terrain.

One's ideas about local weather, soil, plants, and other natural phenomena are the product of generations tinkering with the mechanics of making a living. Thus, epistemological critiques have been made about attempts to translate such knowledge into GIS-based data. For example, Rundstrom (1995: 45) writes, "The Western or European-derived system for gathering and using geographical

20 Orientation by the cardinal directions is central to the concept of mandala. These are the iconographic two-dimensional representations of three-dimension realms referred to widely in the material culture and landscape architecture of the Tibetan-speaking world. Huber (1999: 26) writes, "The tradition of the mandala is one of the most significant hierarchical and replicative special organizing principles to be introduced into Tibet and the rest of Asia from India. Mandalas have served as archetypes of the ideal city, models of the cosmos, blueprints for centers of royal power, templates for the operation of polities, networks for the distribution of resources, plans for sacred architecture, representations of the divine mansion or palace." In other societies, like the Huaorani of Ecuador, for example, cardinal directions are not known; orientation in the rainforests that are their home is based on wholly different principles (Rival 2002).

$21 \quad$ For example, Tibetan Buddhist meditation practices such as the Kalachakra entail visualizing elaborate two-dimensional blueprints of 3-dimensional heavenly abodes. A 3-D computer model of the Kalachakra realm can be viewed as a video at http://kalachakranet.org/mandala_kalachakra.html

22 'Knowledge' has been defined in myriad ways. Barth (1995:66) describes knowledge to refer to "what people employ to interpret and act on the world: feelings as well as thoughts, embodied skills as well as taxonomies and other verbal models." Variously termed as 'indigenous knowledge,' 'traditional ecological knowledge,' or more generally, 'traditional knowledge,' I will refer here to pastoralists' knowledge as the observations, skills, and technologies - as well as social relationships such as norms and institutions - that structure their interactions with the environment (c.f. Fernandez-Gimenez 2000). This kind of knowledge comes in many forms: written documents, oral history, daily practices, and simply the spatial and geographical sense that local inhabitants bring to bear on a landscape. 
information is in numerous ways incompatible with corresponding systems developed by indigenous peoples ... GIS technology, when applied cross-culturally, is essentially a tool for epistemological assimilation." Are the worldviews represented by remotely-sensed images and the Porong Boundary Text compatible or not? Can the ethnographic data I collected from Porong be converted to mappable units? Or was this research project merely an example of 'epistemological assimilation'?

Indeed, it is problematic to assume that knowledge about resource use can be encoded verbally and reduced to words or figures (Roberson 1984; Sillitoe 1998). One's knowledge of the environment lies not in the ideas in our heads but in the world that our predecessors reveal to us. Practical knowledge about survival and livelihood skills like herding, trade, and animal husbandry are absorbed in the doing, watching, and living a particular way of life (c.f. Ingold 2000). Such knowledge (e.g., when a pasture is ready for grazing or how to assist a lamb's birth) are transferred between peers and between generations through action more than expressed through words, much less being written down. Instead, 'knowledge' is expressed and accessed for practical purposes in the moment of action, while carrying out production activities and deciding where to move animals, or amidst squabbles with neighbors. Shown more often than articulated, land management is less about concepts than a set of embodied skills and enacted practices. Following this line, it would not be possible to simply pluck information relating to resource management out of cultural context and treat it as an independent technical fact. In this sense, am I attempting to codify or quantify an inventory of items that cannot simply be entered, sorted, and manipulated in a computer? Certainly, something is lost in translation when oral histories and material culture are transformed into pixels and data bits. But can we glean valuable information nonetheless? I argue, yes, for several interrelated reasons.

GIS can readily integrate two maps produced in the western cartographic tradition: given two mutually intelligible projections of earth's surface, geo-referencing can align the coordinates, topography, and locations quite easily. Naturally, it would have been a great convenience to simply convert the hand-drawn illustrations I elicited in Porong by entering known coordinates and allowing the computer to render accurate maps. But in my case, the hand-drawn maps I had assembled could not be automatically transformed by mathematical algorithms and cartographic logic. Drawing maps is not simply a matter of producing a technical drawing or rendering pre-selected elements in the landscape. The kinds of maps local informants produced were mental representations of their world and its spatial properties. These maps were distinctive and not accurate in the same way that cartographic maps are, with their constant scale and transferability between projections. The scale, distances, angles, and direction of the Tibetans' hand-drawn maps were not precise enough to create a 'meaningful' map in terms of real-world coordinates. Yet if local realities are represented in ways that cannot be adjusted to global projection systems or reconciled with cartographic standards, the effectiveness of participatory maps may be limited to illustrations rather than maps that accurately assert domain (Peluso 1995). The fact that these renderings of Porong's landscape were not drawn according to any set scale or projection systems made it impossible to migrate them automatically into digital format using standard cartographic projections (e.g., Universal Transverse Mercator). Instead, the idea that this process could be automated was abandoned. My own hand would have to intercede, literally.

Many of us like to pore over maps, follow the route of a road, notice the patterns of rivers. Few of us, though, would want to recreate the whole map, contour line by contour line, river by river. Yet this is what I had to do in order to enter the hand-drawn maps into the GIS environment so that these sketches could become part of the spatial model and its analysis. Through the process of digitizing, I created the vertices that made up the polygons comprising pasture boundaries. In this way, I was recreating the outlines of past and present land administration, re-surveying the claims various actors had historically made on Porong's grasslands. Some boundaries followed line of sight, others followed the various bends of rivers, or the contours of ridges in the landscape. I used the computer's mouse to trace points, lines, and polygons from the hand-drawn maps onto a digital base map created from a satellite image. The process devised to integrate these data required triangulation of field observations and photos, GPS points, and satellite images to deduce, decide, and, finally, draw boundary lines to create polygons that represented management units. Digitizing in this way required locating - with acceptable precision - the features named in the boundary text and visually connecting them with the same features on the satellite image. I jumped constantly between the Porong Boundary Text, the hand-drawn maps, a satellite image draped with contour lines, photo images, and, most importantly, the gazetteer. The end result of this digitizing process was a considerably accurate conceptual representation of pasture boundaries in 1884 and 2004.

Another important set of objections to the use of participatory mapping and GIS in social science research and development planning claims that these techniques and technologies are 'antipolitical' (Ferguson 1994); that is, they reinforce and re-create the status quo of power relations (c.f. Dunn et al 1997, Cooke and Kothari 2001). The postmodern turn in the history of cartography has wrested the discipline away from empiricist interpretations of maps as mere representations of a real geography toward more critical assessments of maps as technologies of power (c.f. Harley 1988, 
Pickles 1995, Abbot et al 1998). Led by theorists of space and landscape, we have come to understand that such technologies are not wielded in a vacuum (c.f. Harvey and Chrisman 1998, Basso 1996). In this vein, scholars from diverse disciplines have considered the relationship between mapping and the practices of colonialism (c.f. Edney 1997, Mignolo 1995, Warhus 1997, Watts 1992). Part of the power of maps lies in the fact that they have always served empires: the activities of survey, marking, naming, and mapping make space 'legible' for state-sponsored efforts to settle and control populations, particularly mobile groups (c.f. Scott 1998). ${ }^{23}$ Maps, together with techniques of accountability like inventory record-keeping, have been central to modernization projects whereby the state attempts to simplify diverse and complex social phenomena, such as local practices of land tenure, for the purposes of controlling and manipulating its subjects (c.f. Carney and Watts 1990, Heasley and Delehanty 1996, Peluso 1992). Therefore one must be reflexive in the creation of new maps. Nevertheless, this case study quite forthrightly accepts the proposition that the Porong Boundary Text is manifestly an instrument of power: a legal, binding written agreement that was backed by coercion.

A few words of caution, then, are in order for those who would employ simulation technology such as GIS to model and understand complex social realities. It is difficult to depict power relations on a screen. Attempts to merge scientific approaches with historical narratives can be limited in the sense that they subvert the peculiarities of historical events to the logic of deductive reasoning (Johnson 2004). Turning land use issues, which are very complicated transactions of politics, economics, and society, into bounded technical problems amenable to computational solution risks erasing internal community politics and ignoring the historical and regional context in which communities exist.

The process of generating and controlling information flow certainly created power dynamics: this researcher was slotted into complicated and nested social and economic hierarchies. There were also fiduciary implications: I was paying the government-assigned researcher from the Tibet Academy of Social Sciences, field assistants in Porong, and a driver, along with the occasional meal and beer for an interviewee. In a real sense, then, I controlled the production of knowledge. Once data has been collected, the node of knowledge production becomes one GIS programmer, who is making a series of technical and epistemological decisions. But such exercises need not be solely elitist or anti-political. At the very least, participatory maps do not require literacy: they demand instead the ability to relate to information in geographic terms. Mapmaking was a relatively straightforward way to elicit local knowledge and facilitate discussion within communities.

There are serious democratic limits to such participatory mapping exercises. Nancy Peluso (1995: 387) correctly notes that mapping is "unlikely to become a 'science of the masses' simply because of the level of investment required ... to challenge the authority of other maps." Drawing from my own experience, I would nuance these views. Certainly the price tag associated with purchasing software, hardware, and data for a GIS analysis is restrictive. These prohibitive costs, in turn, play an important structuring role in how mapping is facilitated and by whom. But put an inexpensive and rugged GPS unit in the hand of a curious self-didact like my guide in the field, and the empowering and collaborative aspects of mapping are readily seen. In the field, herders led me through myriad historical puzzles, and I was more than happy to follow my companions' idiosyncratic leads to unanticipated insights and serendipitous data collection. In this project, map making sparked many fruitful conversations about local landscapes. The act of drawing maps became a visual form of conversation that precipitated many 'floodgate' moments of information. In these regards, many choices that were made during this field research were initiated and controlled by my local collaborators. Aware of the critiques of participatory GIS, I contend that there is a leveling and democratizing effect that occurs when people sit down together over maps. Maps facilitate dialogue and, to some extent, limit subjectivity in the interpretation of landscapes. Describing the process I adopted to assimilate an historical text into a digital mapping environment while still keeping intact local idioms is itself a fruitful way of peeling back assumptions and episteme at the core GIS.

\section{Results and Discussion}

With these critiques in mind, I now turn to the spatial analysis. The results reported here are based on the following core data: the Porong Boundary Text, hand-drawn participatory maps, field surveys, and ethnographic interviews. The integration of these data allowed me to transform an historical text and in situ observations into a spatial database and digital maps that could be analysed using GIS applications. Combining maps of Porong's historical and contemporary boundaries with layers of remotely-sensed vegetation data subsequently allowed me to examine the relative distribution of common property resources over time.

23 Scott (1998:78) writes: "an illegible society ... is a hindrance to any effective intervention by the state, whether the purpose ... is plunder or public welfare." 
Pastoral production is based on a matrix of natural resources, which must be organized into viable units for use by multiple herding households. I use the term 'management unit' to indicate those areas which encompass common property resources such as pastures and water and which are uniquely identified with, and claimed by, small-scale political units. A viable management unit must supply the principal grazing resources needed by a herding group to carry out livestock production. The spatially-oriented goal of this research, then, is to test whether the relative availability of common property resources has remained constant or been transformed as a result of reconfigurations in the size and number of management units.

In order to address this analytic goal, the first set of questions to which I sought answer is whether common property boundaries - in either the historical or contemporary period - were simply a function of landscape features. In other words, were/are Porong's borders simply composed of environmental elements like ridges, mountain peaks, or bodies of water? This, in effect, is the null hypothesis: common property boundaries are significantly correlated with certain physical conditions. Indeed, boundaries in the Porong Boundary Text are prevalently identified by and placed along natural features, particularly ridges and rivers. For example, we find this description of the boundaries that defined the skyu mdog management unit:

... having gone along the ridge of gzhu shub lung to its peak, go directly east to the rgun 'brulpa river and stop at the rock called 'og phong. Then go from northern pass directly to the highest peak. (lines 21-24)

In addition, certain segments of Porong's borders are necessarily physical. For example, the Himalayan peaks situated along the southern margins of this region form a natural and imposing boundary. But are boundaries merely, or completely, based on landscape features? No. For all the boundary points marked by environmental elements, I recorded hundreds of vertices that were linked to human-made features, especially corrals. Moreover, there were many instances where the historical boundaries of a management unit were no longer found, or were alternatively placed in the contemporary context, though they had previously been marked as being located along rivers, ridges, and other natural features. In order to understand the location, shape, and size of common property units, then, we must look for alternate explanations, beyond strictly ecological ones.

The compiled maps bring out key continuities and discontinuities in pastoral boundaries and common property regimes, which turn out to be neither fixed in time or space. Once I completed digitization of the historical and contemporary boundary maps, it became immediately obvious that, between 1884 and 2004, there had been a consolidation in Porong's management units from 20 to 12 , as seen in Figure 2. This figure shows that both the size and shape of common property units have been reconfigured and that there are significant divergences in boundary lines. These maps make graphically visible the fact that common property regimes in this nomadic region are more complex and have been more elastic than an environmentally-determined account would have predicted. In the case of Porong, common property units were revealed to be rough-edged, checker-boarded, and irregular polygons welded together by historical circumstance, cultural synergies, and the politics of power, as well as by the uses and constraints of geography and ecology.

Changes in the dimensions of Porong's various management units can be traced to the administrative restructurings which occurred during collectivization period (1967-1980) and the post1980 reform era, which resulted in new boundary lines being drawn. During the commune period, Porong's pastoral encampments were unified into single administrative organizations only to be redivided (from two work brigades to nine natural villages) during the reform era. In both periods, the rhetorical emphasis of the government, at least, was on redistributing productive economic resources along lines that were more egalitarian than the feudal era; whether or not these realignments were successful in achieving these goals is one of the questions addressed by this research. 
The consolidation in management units speaks to important differences in the systems of kinship and descent practiced - and, therefore, also of property relations - in pastoral versus agricultural systems. In an agricultural system, we might anticipate a continual process of division in productive resources with demographic change, as arable fields are divvied out among sons. ${ }^{24}$ However, in a pastoral system, the assets that are passed onto the next generation are animals (which have the potential to expand) rather than land. Typically, common property resources in pastoral systems (pastures, water, etc) are retained at the communal level and are not subject to division as a result of household fission. In this respect, one might have anticipated that the number and size of management units in Porong would have remained the same between 1884 and 2004. These general rules of descent render my results all the more interesting because there is a clear consolidation of communal resources over time, despite the growth in both livestock and human populations reported by the Tibetan government (Fischer 2005). Preliminarily, then, these maps indicate that the processes of boundary making and resource distribution were, indeed, subject to forces that were social and political in nature.

1884

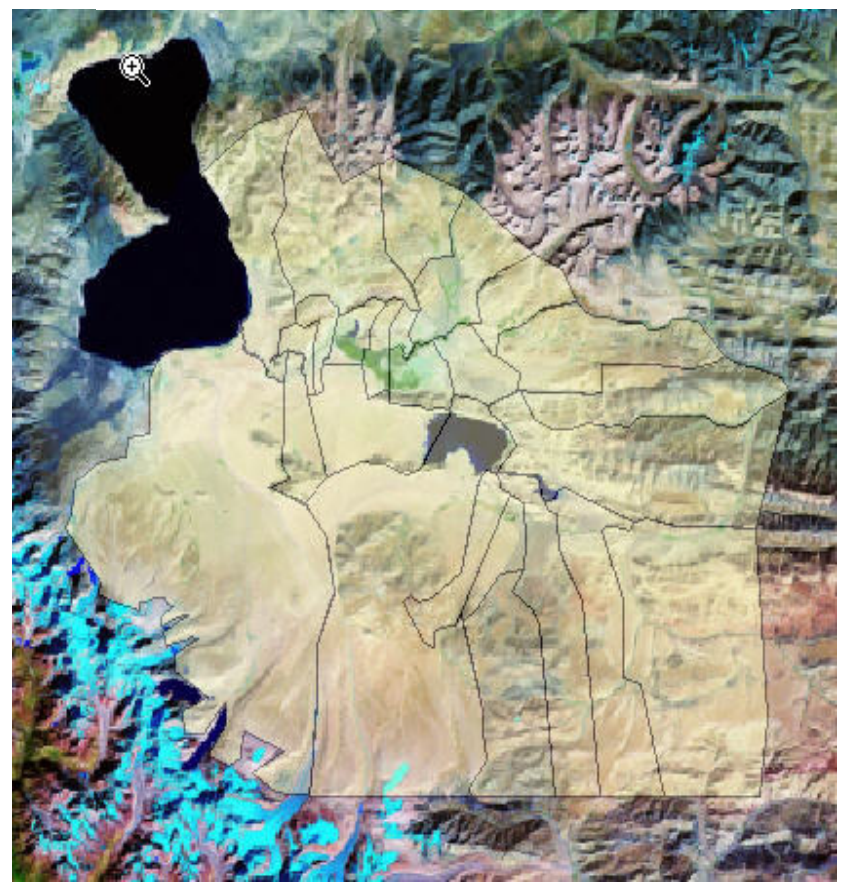

2004

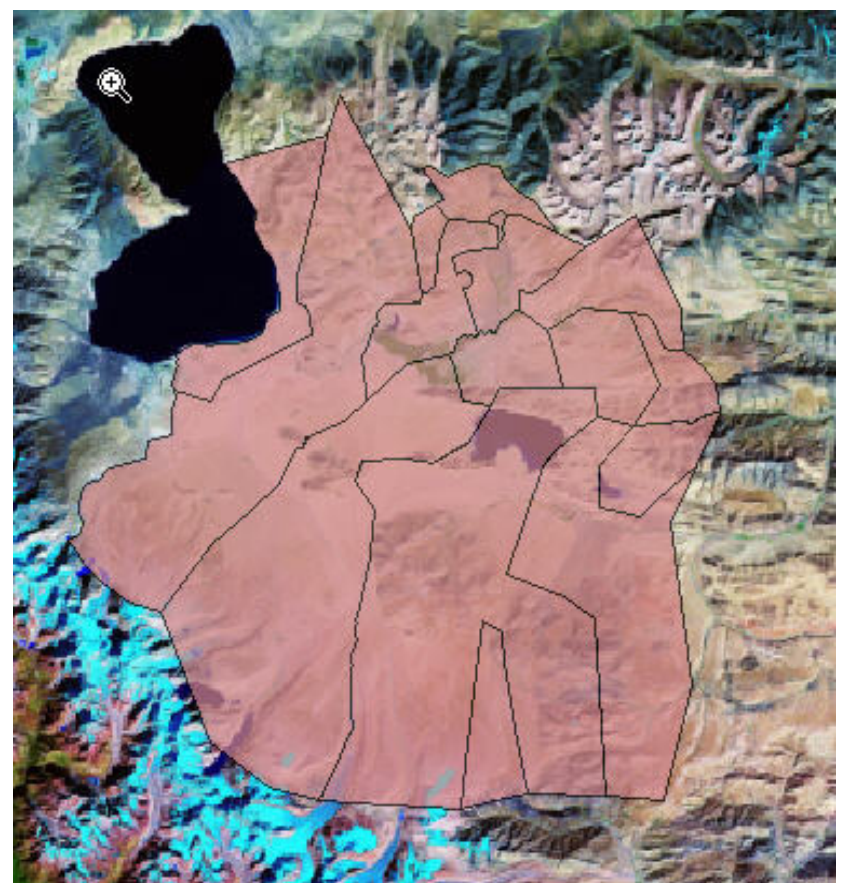

Figure 2: Porong's Management Units in 1884 and 2004

The next objective of the spatial analysis was to test whether the rangeland resources available to Porong herders had remained constant or been transformed consequent to reconfigurations in the size and number of management units. In the process of consolidation depicted in Figure 2, eight historical management units were assimilated into other units: necessarily, some contemporary management units increased significantly in size. Table 1 quantifies some of these changes in the dimensions of Porong's management units between 1884 and 2004. This table lists the eight settlements that today comprise Porong Township; the remaining four management units (of twelve) mapped in the 2004 period are shared parcels.

$24 \quad$ Alternately, in the Tibetan context, social systems of primogeniture and polyandry as well as high rates of participation in celibate monkhood counteracted continuous division of farming lands. 
Table 1 impresses upon the observer the fact that some units, specifically be rtse, chos ding, bra chen, and zhabs $k a$, increased substantially in area: this is particularly true of the be rtse unit, to which several historical units were added.

\begin{tabular}{|l|l|l|l|}
\hline \multirow{2}{*}{ Management Unit } & \multicolumn{2}{l|}{ Area (meters $^{2}$ ) } & \\
\cline { 2 - 4 } & $\mathbf{1 8 8 4}$ & $\mathbf{2 0 0 4}$ & $\begin{array}{l}\text { \% } \\
\text { change }\end{array}$ \\
\hline be rtse & & & +1230 \\
\hline bor mo & 24,165 & 297,136 & -45 \\
\hline chos ding & 93,539 & 51,269 & +304 \\
\hline gser lung & 124,200 & 377,417 & -4 \\
\hline ngo yon & 522,722 & 503,506 & +81 \\
\hline bra chen & 40,344 & 72,865 & +403 \\
\hline skyu mdog & 15,968 & 64,317 & -39 \\
\hline zhabs ka & 96,053 & 58,360 & +539 \\
\hline
\end{tabular}

Table 1: Percentage Change in Area of Management Units, 1884-2004

Simply calculating differences in area, though, gives insufficient proof of the relative availability of resources that Porong's various management units have had in the feudal and socialist periods. The next set of GIS analyses address the issue of the relative availability of resources over time within Porong's different management units. Rather than simply comparing the size or dimension of historical and contemporary management units, I sought to evaluate their 'contents' to see how Porong's management units fared during this period of political transitions and social upheaval.

Comparing bio-productivity levels within and between management units makes it possible to characterise differential availability of rangeland resources over time. As a metric of resource availability, I focused on vegetation and used Normalized Difference Vegetation Index (NDVI) values. ${ }^{25}$ Since I had no access to data on historical pasture conditions, I averaged six years' of NDVI data (2000-2006) and derived mean values for historical and contemporary management units. Given this absence of historical vegetation data, these results comparing time periods must be considered in terms of relative rather than absolute values.

A critical caveat must be aired in relation to the use of NDVI values. These data provide a way of describing the range of photosynthetic activity in a given area. From NDVI images, it is possible to derive productivity values in terms of how much biomass is produced in a given period. However, NDVI values do not measure the nutritional value of vegetation (e.g., nitrogen content). In other words, an area that registers as less active via NDVI sensors may in fact contain more nutritional value than an adjacent locale with higher NDVI readings. Furthermore, NDVI values cannot inform us of other landscape values - such as access to water, salt licks, or sources of fuel - that make one area more or less attractive than another, either to animals or to humans. Finally, as noted above, the NDVI values used here are limited to the period between 2000 and 2006 since remotely sensed vegetation data is unavailable for the historical period. Given changes in the global climate or smaller-scale alterations in other factors such as hydrology that affect bio-productivity, it is possible that certain management units have experienced localized changes in vegetation since the $19^{\text {th }}$ century that cannot be accounted for using the methods adopted here. Despite these limitations, the results that follow reveal clear patterns in the relative productivity of Porong's different management units and show how the availability of these resources has changed over time.

In order to compare the productivity of management units, I compiled a series of NDVI images that showed vegetation growth over $1 \frac{1 / 2}{2}$ month periods according to the Tibetan system: these 45-day periods parallel the 'upper' (yar) and 'lower' (smad) halves of each season according to Tibetan

25 NDVI is a calculation for measuring plant growth based on photosynthetic activity. Every plant species absorbs and reflects the sun's radiation in unique 'registers' which sensors record as surface reflectance values. NDVI can be used as an indicator of relative biomass and greenness (Chen 1998). NDVI values are a useful metric for plant productivity, particularly in the absence of on-the-ground measurements. Combining NDVI values with geographical layers allowed me to depict where, when, and how actively vegetation was growing on the Porong landscape at discrete moments. 
sensibilities. Table 2 converts between the Tibetan and Gregorian calendars, and Table 3 links NDVI for 2000-2006 to historical management units by season.

\begin{tabular}{|l|c|c|c|c|}
\hline Season & \multicolumn{2}{|c|}{ Tibetan Season } & ID & Gregorian Month \\
\hline Winter & dgun & yar & $\mathrm{a} 1$ & December 1 - January 15 \\
\cline { 3 - 5 } & & smad & $\mathrm{a} 2$ & January 16 - March 1 \\
\hline \multirow{2}{*}{ Spring } & dpyid & yar & $\mathrm{b} 1$ & March 2 - April 15 \\
\cline { 3 - 5 } & & smad & $\mathrm{b} 2$ & April 16 - May 30 \\
\hline \multirow{2}{*}{ Summer } & dbyar & yar & $\mathrm{c} 1$ & June 1 - July 15 \\
\cline { 3 - 5 } & & smad & $\mathrm{c} 2$ & July 16 - August 30 \\
\hline Fall & \multirow{2}{*}{ ston } & yar & $\mathrm{d} 1$ & September 1 - October 15 \\
\cline { 3 - 5 } & & smad & $\mathrm{d} 2$ & October 16 - November 30 \\
\hline
\end{tabular}

Table 2: Conversion System between Tibetan and Gregorian Calendars

In the historical (1884) period, three units - bra chen, bsil gsum, bor mo - have the highest mean NDVI values in every season, indicating that the distribution of vegetation resources in common property units was not equal within Porong (Table 3). These findings show graphically the differences that existed historically between units: for example, the mean NDVI values for bra chen in the summer are at least $35 \%$ higher than $85 \%$ of the management units. This indicates that the feudal structuring of common property relations resulted in disparities in the kinds of resources which were available to herders.

\begin{tabular}{|c|c|c|c|c|c|c|c|c|c|}
\hline \multirow{2}{*}{$\begin{array}{l}\text { Management } \\
\text { Unit }\end{array}$} & \multicolumn{9}{|c|}{ Season } \\
\hline & a1 & a2 & b1 & $\mathrm{b} 2$ & $\mathrm{c} 1$ & $\mathrm{c} 2$ & d1 & $\mathrm{d} 2$ & $\begin{array}{c}\text { Average } \\
\text { Rank }\end{array}$ \\
\hline bra chen & 2 & 1 & 1 & 1 & 1 & 1 & 1 & 1 & 1 \\
\hline bsil gsum & 4 & 2 & 2 & 2 & 2 & 2 & 2 & 2 & 2 \\
\hline bormo & 1 & 3 & 3 & 3 & 3 & 3 & 3 & 3 & 3 \\
\hline skyu mdog & 7 & 5 & 4 & 5 & 6 & 5 & 5 & 4 & 5 \\
\hline spe skye & 3 & 6 & 6 & 9 & 4 & 4 & 4 & 5 & 5 \\
\hline ngo yon & 6 & 4 & 5 & 6 & 7 & 9 & 6 & 7 & 6 \\
\hline sbra po che & 5 & 7 & 7 & 8 & 9 & 8 & 7 & 6 & 7 \\
\hline gter kog & 11 & 9 & 15 & 13 & 5 & 6 & 8 & 8 & 9 \\
\hline be rtse & 8 & 8 & 10 & 16 & 16 & 11 & 13 & 9 & 11 \\
\hline zam sne & 10 & 18 & 8 & 4 & 10 & 13 & 10 & 15 & 11 \\
\hline btsan lam & 14 & 16 & 17 & 18 & 11 & 7 & 9 & 12 & 13 \\
\hline phu dmar & 9 & 11 & 13 & 15 & 19 & 19 & 16 & 11 & 14 \\
\hline gnya dgar & 20 & 21 & 12 & 7 & 8 & 10 & 11 & 21 & 14 \\
\hline chos ding & 18 & 15 & 14 & 12 & 17 & 18 & 15 & 13 & 15 \\
\hline sum phug & 13 & 15 & 14 & 12 & 17 & 18 & 15 & 13 & 15 \\
\hline zhabs ka & 17 & 13 & 18 & 20 & 14 & 14 & 17 & 16 & 16 \\
\hline spab ri & 16 & 12 & 16 & 17 & 18 & 16 & 19 & 17 & 16 \\
\hline gser lung & 21 & 22 & 21 & 11 & 12 & 12 & 20 & 20 & 17 \\
\hline tshe gyal & 15 & 19 & 19 & 22 & 20 & 17 & 18 & 18 & 19 \\
\hline thar dpe & 19 & 14 & 20 & 21 & 22 & 21 & 21 & 19 & 20 \\
\hline
\end{tabular}

Table 3 Rank of Mean NDVI Values (2000-2006) for Historical Management Units 
It is important to consider the possibility that, even though the analysis presented here indicates that some management units were clearly richer than others, density dependent dynamics may have leveled out the quantity and quality of resources in Porong's pasture areas so that all its management units were, in effect, similarly productive (i.e., the ratio of grazer/grazed was equal throughout the area). For example, if the bra chen unit contained 50\% of Porong's available productive resources but was also grazed by $50 \%$ of Porong's livestock animals, this unit may, in effect, have been no better off than a unit with less productive resources but fewer animals.

Figure 4 shows that a significant leveling of average productivity has occurred in management units since 1884. Yet, as we shall see, the relative distribution of resources is more complicated than these initial figures suggest and our judgments must, for now, remain suspended. To elaborate, an important element of the contemporary situation is the fact that some management units share parcels, adding to the common pool resources to which they have access.
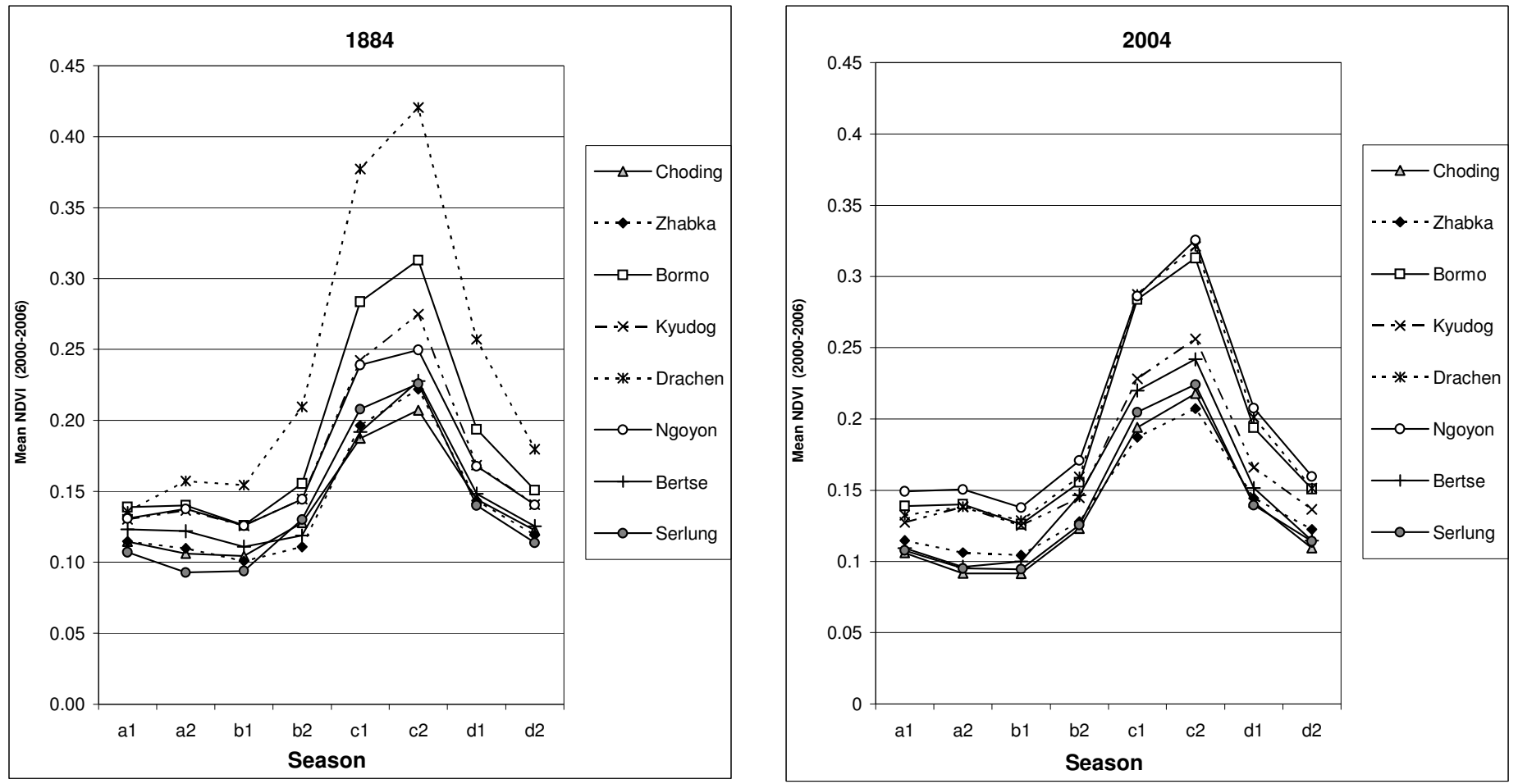

Figure 4: Average Productivity of Vegetation within 1884 and 2004 Boundaries

Table 4 indicates that the resources found within these shared parcels can be considerable: for example, the shared unit sbra chen, ngo yon, bor mo, chos ding ranks fourth overall among Porong's contemporary units in terms of NDVI values. Access to these shared parcels must therefore be included as a critical element in any judgments concerning the relative availability of grassland resources within different management units. Table 5 directly compares the ranking of NDVI values for management units extant in both 1884 and 2004. These rankings show that, despite a narrowing of the gap between management units in terms of availability of productive resources, the hierarchy of distribution remained quite persistent through the 1884 and 2004 period..

These tables and figures synthesize a number of important observations regarding the relative availability of resources within Porong's management units between 1884 and 2004. First, they graphically show that within periods, Porong's management units are unequal in terms of the productive resources they contain, as measured by NDVI values. Second, despite significant alterations in the location of boundaries and the areas they contain, there are important continuities in resource distribution between 1884 and 2004. For most of Porong's management units, alterations in boundaries have not caused significant changes in average NDVI values, supporting the argument that, in order to be viable, common property must be based on units that can ecologically support livestock production. Third, the changes observed in the distribution of resources in Porong underscore the fact that common 
property boundaries are driven by dynamics beyond mere ecology, in this case the shift from feudalism to socialism and the incumbent effects of this transformation on Tibet's political economy and culture.

\begin{tabular}{|l|l|l|l|l|l|l|l|l|c|}
\hline \multirow{2}{*}{ Management Unit } & \multicolumn{9}{|c|}{ Rank by Season } \\
\cline { 2 - 12 } & $\mathrm{a} 1$ & $\mathrm{a} 2$ & $\mathrm{~b} 1$ & $\mathrm{~b} 2$ & $\mathrm{c} 1$ & $\mathrm{c} 2$ & $\mathrm{~d} 1$ & $\mathrm{~d} 2$ & $\begin{array}{c}\text { Average } \\
\text { Rank }\end{array}$ \\
\hline bra chen & 5 & 4 & 11 & 1 & 2 & 1 & 1 & 2 & 3 \\
\hline $\begin{array}{l}\text { bra chen, ngo yon, bor } \\
\text { mo, chos ding (shared } \\
\text { parcel) }\end{array}$ & 2 & 2 & 13 & 2 & 4 & 2 & 2 & 1 & 4 \\
\hline bor mo & 3 & 3 & 9 & 7 & 5 & 3 & 4 & 5 & 5 \\
\hline $\begin{array}{l}\text { zhabs ka, gser lung, be } \\
\text { rtse (shared parcel) }\end{array}$ & 1 & 1 & 12 & 6 & 9 & 7 & 5 & 3 & 6 \\
\hline be rtse & 9 & 10 & 5 & 4 & 1 & 9 & 9 & 10 & 7 \\
\hline skyu mdog & 6 & 5 & 10 & 5 & 8 & 6 & 7 & 6 & 7 \\
\hline $\begin{array}{l}\text { ngo yon, skyu mdog, bor } \\
\text { mo (shared parcel) }\end{array}$ & 8 & 8 & 9 & 6 & 7 & 8 & 8 & 8 & 8 \\
\hline gser lung & 10 & 9 & 4 & 10 & 10 & 10 & 11 & 9 & 9 \\
\hline chos ding & 11 & 11 & 3 & 11 & 11 & 11 & 10 & 11 & 10 \\
\hline zhabs ka & 13 & 13 & 1 & 12 & 12 & 12 & 12 & 12 & 11 \\
\hline
\end{tabular}

Table 4: Rank of NDVI Values (2000-2006) for Contemporary Management Units

\begin{tabular}{|c|c|c|}
\hline $\begin{array}{c}\text { Management } \\
\text { Unit }\end{array}$ & $\begin{array}{c}\text { Average } \\
\text { Rank in } \\
1884\end{array}$ & $\begin{array}{c}\text { Average } \\
\text { Rank in } \\
2004\end{array}$ \\
\hline bra chen & 1 & 3 \\
\hline bor mo & 3 & 5 \\
\hline be rtse & 11 & 7 \\
\hline skyu mdog & 5 & 7 \\
\hline gser lung & 17 & 9 \\
\hline chos ding & 15 & 10 \\
\hline zhabs $k a$ & 16 & 11 \\
\hline
\end{tabular}

Table 5: Rank of NDVI Values for Management Units in 1884 and 2004

Two management units - bra chen and zhabs $k a$ - illustrate well the dynamics of resource availability in Porong's management units. The historical management unit bra chen was the domain of the Jewön, the hereditary ruler of Porong. Within the area covered by this management unit, in every season except the first half of winter (a1), the mean NDVI values are higher than any other unit in Porong. That is, at almost any moment during the year, the Jewön (and those subjects who had rights to use land within this area) had access to grazing areas that were, on average, more productive than any other area in the vicinity. This observation is corroborated in the average ranking of mean NDVI values (Tables 3-5) as well as the charts depicting mean NDVI values in the historical and contemporary periods (Figures 3 and 4). That the bra chen unit - the most powerful constituency in Porong - should have had access to the most productive resources during the feudal era comes as little surprise. Given the socialist government's intensive focus on redistributing economic assets after 1959, what is surprising, perhaps, is that in the contemporary period as well this unit retained the highest average rank in terms of mean NDVI values, as seen in Table 4. Thus, even though this management unit may have seen a decline in the productive resources found within its boundaries, its members continue to enjoy relatively superior resources. In this sense, bra chen illustrates at the local level the preservation of capital (in the form of resources) as opposed its devolution despite marked transformations in the structure of Tibet's overall political economy. 
There are several possible explanations for this status quo. It is plausible that the number of animals grazing the bra chen unit declined between 1884 and 2004, lessening grazing pressure on pastures in this area and thereby resulted in the maintenance of high productivity resources, even as the actual spatial area of this management unit declined. Interviewees in Porong did mention that animal numbers in Porong had, in fact, dropped during two distinct periods: (1) the years immediately following the exile of the Dalai Lama and the departure of much of Tibet's ruling class; (2) the collectivization period, during which livestock numbers were depressed throughout the TAR. Yet the phenomenon of decreasing livestock numbers and concomitant effects on grazing pressure would not have been isolated to the bra chen unit. Still, according to local informants, when compared with other Porong management units, the bra chen unit today has relatively fewer households and fewer animals in the contemporary period than it did during the feudal era, particularly with the absence of the Porong Jewön and his herds.

A key limitation of this study, then, is the absence of historical data on the composition and location of livestock and human populations. The former would reveal where and when grazing pressure took place within management units. The latter would allow me to specify where settlement patterns were most dense and, concomitantly, where production activities were concentrated. Without these data, moreover, it is difficult to confidently assess actual access to, and distribution of, resources within management units.

Nevertheless, these patterns of continuity in the relative distribution of resources within management units in Porong indicate that the local socio-political relations implicit in common property boundaries maintained an inertia that was quite resistant to manipulation by external political ideologies and economic influences. Enshrined in generations of socially- and ritually-reinforced praxis, the comparative advantages of common property territories were retained: management units inherited their compositional makeup in terms of vegetation resources even as boundary lines changed. Arguably, these results show that the reach of the state - even at its totalizing zenith during the commune era - had strong limits. Conversations with residents of Porong revealed that certain individuals, particularly the literate and lineal members of Porong's various encampments, played key roles in bridging administrations and helped to maintain the status quo in terms of resource availability through their multiple roles as enforcers, advocates, and interpreters of common property boundaries. Even at the ideological height of state intervention in Tibet, township and county cadres relied on intermediates to help them govern, particularly in relation to administering natural resources. Thus, the political and social variables which I have attempted to highlight as being central to the dynamics of common property should not be seen solely as top-down. Rather, these political and social dynamics operate at several levels and include local agency.

The phenomenon of reciprocal use agreements further complicates the analysis of common property regimes in Tibetan pastoral areas, since it results in greater difficulty in uniquely identifying claims to rangeland resources, which tend to be used in socially and spatially flexible ways. First, given the mobility inherent to this production system and the highly variable nature of rangeland resources, it is problematic to fix maps or assign boundaries to areas that are putatively used by an exclusive and identifiable group. The results reported here must account for the fact that herders do not interpret common property boundaries as hermetically sealed borders. In fact, as ethnographic work revealed, local understandings of resource use rights in Porong are multiple. For example, privileges to graze in communally-shared pastures are extended to traders passing through Porong and to fictive kin (T., nas tshang), who are granted the right to graze their animals on common property pastures. Moreover, resource users with rights to less productive management units frequently have access to resources in others' parcels, as we have seen in the results reported above. Porous boundaries fulfill certain important functions, including the facilitation of movement between pastures and access to water sources. Resource sharing agreements enable such access, which is critical for achieving a balance between unimpeded access for member households to an effective combination of resources characterized by heterogeneity and effective jural rules limiting resource exploitation (c.f. Wolf 1972).

That common property resources are embedded within moral economies and are, therefore, socially porous is aptly illustrated by the Porong Boundary Survey. In the example below, I show how herders could make use of reciprocal resource use rights and other socially-embedded mechanisms to contend with their inherently risky, high-altitude environment. The Porong Boundary Survey makes explicit inter-community resource sharing arrangements. For example, a toponym recorded as, "west of the shepherd's spring in the river bend where the swamp grass grows" (T., lu ma skye skyog nub kyi $r d z i$ skyul) was located one day during fieldwork. It lay at the bottom of a steep ridge. North of here, our guide oriented us, were the boundaries of Ngoyon and its neighbor, Tingdum Village. We were informed that, during the winter, Tingdum Village lacks water. In the text it reads, "During the winter, the people of Tingdum may use the Ngoyon path to approach the spring called Kyekyog (T., skye skyogs)." In this manner, these two communities had worked out a way to share water during the winter, a practice embedded in customary norms and legitimated in the text as law. That agreement is 
still being honored, 120 years after the Porong Boundary Survey was recorded, persistent despite the tumult of Tibet's recent history.

Despite these mechanisms for the redistribution of resources, we must also account for differences between households within a given management unit, i.e., the relative access of different users who claim rights to the same set of resources bounded by common property boundaries. For example, differences in household demographics and livestock herds may significantly affect the use of, and access to, common property even though individuals within a given unit ostensibly have the same rights to productive resources. For example, the largest herd of sheep in Porong Township is currently (2004) owned by a household from gser lung. Though the average rank of NDVI values for the gser lung unit is relatively low ( $9^{\text {th }}$ out of 12 units), this household may, by dint of animal numbers and available labour, effectively monopolise this management unit, skewing resource distribution in ways that cannot be detected from space. Conversely, households in a management unit that appears relatively richer (in terms of average NDVI values or area covered by productive vegetation) may not be able to take advantage of these resources as a consequence of insufficient labour, lack of capital, or other key production factors. Classifications of vegetation based on remotely-sensed NDVI data can help capture the relative productivity of resources. However, a confluence of other factors such as demographic change and out-migration determines whether herders within a particular management unit fared better or worse in terms of access to productive resources over this period.

Beneath the seemingly fixed divisions of common property units mapped here, the reality is that one would find a great deal of variation in grazing pressure and stocking rates in any given area of Porong. Day-to-day rangeland management in common property resource areas is the cumulative result of myriad, fine adjustments that are made by each household simultaneously. For example, the size, composition, and location of one's herd may shift as a result of reciprocal labour obligations or the disbursal of household animals in the event of death or on the occasion of marriage. Local officials in Porong do not control day-to-day grazing movements but they do dictate the dates for seasonal movements. Their most important role, according to local informants, is in mediating inter-township conflicts over pasture resources, which reinforces the contention that state agents continue to play critical roles in determining the location of common property boundaries. Township officials also collect an annual per livestock head fee from Porong's herders. Township and county cadres are also closely involved in soliciting funds, organizing installation labor, and for fenced enclosures, an increasingly prevalent livestock management tool that is bound to affect property relations.

\section{Conclusions}

The maps of Porong's management units reveal that pasture boundaries have changed significantly over time, and in ways that cannot be wholly explained through ecologically-driven factors. These results have useful and critical implications for assessments of pastoral systems by common property theorists. 'Traditional' or 'local' systems of resource management have never been autonomous or free of entanglement with larger political and economic processes. This case study provides evidence that state regulation has been endemic to the coordinating and disciplinary structures we see in common property regimes among Tibetan pastoralists. Documents like the Porong Boundary Survey attest to the long-standing importance of state entities in defining boundaries and mediating conflicting resource claims amongst pastoral groups in Tibet. As such, a key problem with relating the common property literature - much of which is based upon empirical studies of pastoral regions in Africa - to Tibet or greater Central Asia is the open-ended nature of resource boundaries in the sub-Saharan regions (Behnke 1994). By contrast, in Central Asia, property rights and boundaries were typically carefully recorded in successive series of legal documents and were settled by adjudication mechanisms that were equally well developed. ${ }^{26}$ Boundary survey documents such as the historical texts from Porong with which I am working were common throughout the Tibetan-speaking world. In other words, when we think about property in Central Asian pastoral regions, we must recognize that, for hundreds of years, through waves of land surveys that legally disposed of public lands, resource use rights and property relations were defined and legitimized through the agency of the state.

GIS mapping and spatial analysis can bring out crucial issues in the political ecology of pastoral areas, with important implications for planning future development. This research has demonstrated an effective methodology for blending time periods and kinds of knowledge when mapping complex phenomena like land use. GIS helps us to visualise how pasture boundaries were delineated historically and how changes in Tibet's political economy did or did not impact the

26 Unfortunately, there are relatively few works on law in Tibetan society that can assist us in teasing out the differences between 'traditional' customary law and today's state regulations (c.f. Uebach 1994, Richardson 1984, Petech 1973, Shakabpa 1967, French 1995, Pirie 2005). 
distribution of resources among pastoralists. In Porong, common property boundaries have been significantly altered since the $19^{\text {th }}$ century. As such, the spatial analysis presented here supports the proposition that access to and use of common property resources is grounded in political and social dynamics.

The boundaries that state entities helped create and maintain were not used to enclose fee simple property. Rather, boundaries may be seen as a strategy for regularizing exchange and a zone of interaction rather than a barrier: fixed or rigid boundaries would have been inconsistent with the Plateau's high risk ecology. One of the many important effects of boundaries in the Tibetan pastoral context has been to formalize reciprocity and exchanges. While reciprocity agreements and social networks allowed for the redistribution of common pool resources, this analysis provides compelling evidence that common property boundaries also reinforce power relations, resulting in unequal access to resources. While resource types and uses are similar across Porong over time, the spatial analysis developed here demonstrates that common property resources were not equally distributed between management units. Thus, even as ecological variables can be construed as the driving mechanisms for how common property regimes are structured, socio-political factors must be cited for how these systems function. These results have useful and critical implications for common property theory particularly with regard to the important and necessary roles that state entities have played and must continue to play in regulating common property regimes and controlling conflicts over resources.

\section{References Cited}

Abbot, J., R. Chambers, C. Dunn, T. Harris, E. de Merode, G. Porter, J. Townsend, and D. Weiner. 1998. "Participatory GIS: Opportunity or Oxymoron?" PLA Notes 33: 27-34.

Arce, A. and N. Long (Editors)

2000. Anthropology, Development and Modernities: Exploring Discourses, Countertendencies and Violence. London: Routledge.

Barth, F.

1995. "Other Knowledge and Other Ways of Knowing." Journal of Anthropological Research 51:65-68.

Basso, K.

1996. Wisdom Sits in Places. Albuquerque: University of New Mexico Press.

Behnke, R.

1994. "Natural Resource Management in Pastoral Africa." Development Policy Review 12:527.

Bennagen, P. and A. Royo

2000. Mapping the Earth, Mapping Life. Quezon City, Philippines: Legal Rights Natural Resources Center.

Boas, F.

1934. Geographical Names of the Kwakiutl Indians. New York: Columbia University Press.

Brown M. and C. Hutchinson

2000. "Participatory Mapping at Landscape Levels: Broadening Implications for Sustainable Development and Biodiversity Conservation in Developing Country Drylands." Arid Lands Newsletter 48. http://ag.arizona.edu/OALS/ALN/aln48/brown\&hutchinson.html, [Accessed 12 November 2006].

Carney, J. and M.J. Watts

1990. "Manufacturing Dissent: Work, Gender and the Politics of Meaning in a Peasant Society." Africa 60:207-237.

Casimir, M., R. Winter, and B. Glatzer

1992. "Nomadism and Remote Sensing: Animal Husbandry and the Sagebrush Community in a Nomad Winter Area in Western Afghanistan." Journal of Arid Environments 3:231-254.

Chambers, R.

1997. Whose Reality Counts? Putting the First Last. London: Intermediate Technology Publications.

Chapin, M., Z. Lamb, and B. Threlkeld

2005. "Mapping Indigenous Lands." Annual Review of Anthropology 34: 619-38. 
Christensen, L., M. Coughenour, J. Ellis, L. Li, Y. Han, and R. Lee 1998. "Land Use Change and Its Effects on Long-term Ecosystem Productivity on the Mongolian Steppe." LUTEA Conference, Beijing, China. http://www.nrel.colostate.edu/projects/lutea/project_activities.htm, [Accessed 12 November 2006].

Christensen, L., M. Coughenour, J. Ellis, L. Li, and K. Price 1999. "An Integrated Assessment of Land Use and Vegetation on the Grasslands of Inner Mongolia." In People and Rangelands: Proceedings of the VI International Rangeland Congress, Townsville, Australia, July 19-23, 1999. Aitkenvale, Australia: VI International Rangeland Congress, Inc.

Cooke, B. and U. Kothari (Editors)

2001. Participation: The New Tyranny? London: Zed Books.

Crook, J. and H. Osmaston (Editors)

1994. Himalayan Buddhist Villages: Environment, Resources, Society, and Religious Life in Zangskar, Ladakh. Bristol, U.K.: University of Bristol.

Diemberger, $\mathrm{H}$.

2002. "The People of Porong and Concepts of Territory." In Territory and identity in Tibet and the Himalayas. Proceedings of the Ninth Seminar of the International Association of Tibetan Studies edited by K. Buffetrille and H. Diemberger, Leiden: Brill. 33-55.

— 1998. "The Horseman in Red: On Sacred Mountains of la stod lho (Southern Tibet)." In Tibetan Mountain Deities: Their Cults and Representations edited by A-M. Blondeau, Wien: Verlag der Österreichischen Akademie der Wissenschaften.

1994. "Mountain-Deities, Ancestral Bones and Sacred Weapons: Sacred Territory and Communal Identity in Eastern Nepal and Southern Tibet." In Tibetan Studies: Proceedings of the 6th Seminar of the International Association for Tibetan Studies edited by P. Kværne, Oslo: Institute for Comparative Research in Human Culture, 144-153.

Diemberger, H., P. Wangdu, M. Kornfeld, and C. Jahoda

1997. Feast of Miracles. The Life and the Tradition of Bodong Chole Namgyal (1375/6-1451

A.D.) According to the Tibetan Texts 'Feast of Miracles' and 'The Lamp Illuminating the History of Bodong."' Bergamo, Italy: Ferrari Grafiche.

Dunn, C., P. Atkins, and J. Townsend

1997. "GIS for Development: A Contradiction in Terms?" Area 29:151-59.

Edney, M.

1997. Mapping an Empire: The Geographical Construction of British India, 1765-1843. Chicago: University of Chicago Press.

Eghenter, C.

2000. Mapping Peoples' Forests: The Role of Mapping in Planning Community-Based Management of Conservation Areas in Indonesia. Washington, DC: Biodiversity Support Program.

Ferguson, J.

1994. The Anti-politics Machine: "Development," Depoliticization, and Bureaucratic Power in Lesotho. Minneapolis: University of Minnesota Press.

Fernandez-Gimenez, M.

2000. "The Role of Mongolian Nomadic Pastoralists' Ecological Knowledge in Rangeland Management." Ecological Applications 10: 1318-1326.

Flavelle, A.

2002. Mapping Our Land: A Guide to Making Maps of Our Own Communities and Traditional Lands. Edmonton, Canada: Lone Pine Foundation.

French, R.

1995. The Golden Yoke: The Legal Cosmology of Buddhist Tibet. Ithaca, NY: Cornell University Press.

Foucault, M.

1972. The Archaeology of Knowledge. London: Tavistock.

1980. Power/Knowledge: Selected Interviews and Other Writings, 1972-1977. Brighton: Harvester. 
Fox, J.

2002. "Siam Mapped and Mapping Cambodia: Boundaries, Sovereignty, and Indigenous Concepts of Space." Society of Natural Resources 15: 65-78.

Fox, J., K. Surayanta, P. Hershock, and A. Pramono

2003. "Mapping Power: Ironic Effects of Spatial Information Technology." Working Paper \#63. Environmental Change and Vulnerability Series. Honolulu: East-West Center.

Goldstein, M.

"The Circulation of Estates in Tibet: Reincarnation, Land and Politics." The Journal of Asian Studies 32(1973): 445-455.

Gonzalez, N., F. Herrera, and M. Chapin

1995. "Ethnocartography in the Darien." Cultural Survival Quarterly 18: 31-33.

Harley, J. B.

1988. "Maps, Knowledge, and Power." In The Iconography of Landscape: Essays on the Symbolic Representation, Design, and Use of Past Environment edited by D. Cosgrove and S. Daniels, Cambridge: Cambridge University Press.

Harvey, F. and N. Chrisman

1998. "Boundary Objects and the Social Construction of GIS Technology." Environment and Planning." A 30(9): 1683-1694.

Heasley, L. and J. Delehanty

1996. "The Politics of Manure: Resource Tenure and the Agropastoral Economy in Southwestern Niger." Society and Natural Resources 9: 31-46.

Hodder, I.

2000. "The Interpretation of Documents and Material Culture." In The Handbook of Qualitative Research (2nd edition) edited by N. Denzin and Y. Lincoln, Thousand Oaks, Calif.: Sage Publications, 703-716.

Hodgson, D. and R. Schroeder

2002. "Dilemmas of Counter-mapping Community Resources in Tanzania." Development and Change 33: 79-100.

Huber, $\mathrm{T}$.

1999. The Cult of Pure Crystal Mountain. Popular Pilgrimage and Visionary Landscape in Southeast Tibet. Oxford: Oxford University Press.

Ingold, T.

2000. The Perception of the Environment: Essays on Livelihood, Dwelling, and Skill. London: Routledge.

Johnson, B.

1997. The Use of Geographic Information Systems (GIS) by First Nations. Vancouver:

School Committee for Regional Planning, University of British Columbia.

http://www.nativemaps.org/?q=node/1247 [Accessed 12 November 2006].

Johnson, C.

2004. "Uncommon Ground: The 'Poverty of History' in Common Property Discourse."

Development and Change 35: 407-433.

Jordan, G.

2002. "GIS for Community Forestry User Groups in Nepal: Putting People before Technology." In Community Participation and geographic information systems edited by W. Craig, T. Harris, and D. Weiner, London: Taylor and Francis, 232-245.

Kind, $M$.

2002. "Abducting the Divine Bride - Reflections on Territory and Identity among the Bonpo Community in Phoksumdo, Dolpo." In Territory and Identity in Tibet and the Himalayas. Proceedings of the 9th Seminar of the International Association of Tibetan Studies (2000) edited by K. Buffetrille, H. Diemberger, Leiden: Brill, 271-288.

King, B.H.

2002. " Towards a participatory GIS: Evaluating case studies of participatory rural appraisal and GIS in the developing world". Cartography and GIS 29(1): 43-52. 
Kosek, J.

1998. "Mapping Politics." Common Property Resources Digest. 45: 4-6.

McCracken, S., E. Brondizio, D. Nelson, E. Moran, A. Siqueira, and C. Rodriguez-Pedraza 1999. "Remote Sensing and GIS at Farm Property Level: Demography and Deforestation in the Brazilian Amazon." Photogrammetric Engineering \& Remote Sensing 65: 1311-1320.

Mbile, P., D. Okon, and A. Degrande

2003. "Integrating Participatory Resource Mapping (PRM) and Geographic Information Systems (GIS) in humid lowland sites of Cameroon, Central Africa: a methodological guide." Electronic Journal of Information System Development in Cities 14: 1-11.

Mignolo, W.

1995. The Darker Side of the Renaissance: Literacy, Territoriality and Colonization. Ann Arbor, Michigan: University of Michigan Press.

Mosse, D.

1994. "Authority, Gender and Knowledge: Theoretical Reflections on the Practice of Participatory Rural Appraisal." Development and Change 25: 497-525.

Nelson, N. and S. Wright (Editors)

1995. Power and Participatory Development: Theory and Practice. London: Intermediate Technology Publications.

Nyelam County Animal Husbandry Bureau (Nyelam AHB)

2003. "Application for the Construction of Livestock Shelters in Porong Xiang." November $28,2003$.

Orlove, B.

1991. "Mapping Reeds and Reading Maps: The Politics of Representation in Lake Titicaca." American Ethnologist 18: 235-273.

Peluso, N.

1995. "Whose Woods are These? Counter-mapping Forest Territories in Kalimantan, Indonesia." Antipode 27: 383-406.

Petech, L.

1973. Aristocracy and Government in Tibet 1728-1959. Roma: Instituto Italiano per il Medio ed Estremo Oriente. Serie Orientale Roma 45.

Pickles, J. (Editor)

1995. Ground Truth: The Social Implications of Geographic Information Systems. New York: Guilford Press.

Pirie, F.

2005. "Segmentation Within the State: The Reconfiguration of Tibetan Tribes in China's Reform Period." Nomadic Peoples 9: 83-102.

Rambaldi, G. and D. Weiner

2004. Third International Conference on Public Participation GIS: Track on International Perspectives. Madison: University of Wisconsin, July 18-20, 2004. www.iapad.org/publications/ppgis/PPGIS_2004_Intl_track_summary.pdf , 2004 [Accessed 12 November 2006].

Ramble, C.

2002. "The Victory Song of Porong." In Territory and identity in Tibet and the Himalayas. Proceedings of the Ninth Seminar of the International Association of Tibetan Studies edited by K. Buffetrille and H. Diemberger, Leiden: Brill. Part 1.

— 1996. "Patterns of Places." In Reflections on the Mountain: Essays on the History and Social Meaning of the Mountain Cult in Tibet and the Himalaya edited by A-M. Blondeau and E. Steinkellner, Vienna: Verlag der Österreichischen Akademie der Wissenschaften, 141-152.

1995. "Gaining Ground: Representations of Territory in Bon and Tibetan Popular Tradition." Tibet Journal 20: 83-124. 
Rasmussen, M., R. James, T. Adiyasuren, P. Khishigsuren, B. Naranchimeg, R. Gankhuyag, and B. Baasanjargal

1999. "Supporting Mongolian Pastoralists by Using GIS to Identify Grazing Limitations and Opportunities from Livestock Census and Remote Sensing Data." GeoJournal 47: 563-571.

Richardson, H.

1984. Tibet and Its History. Boston: Shambala.

Rival, L.

2002. Trekking Through History: The Huaorani of Amazonian Ecuador. New York: Columbia University Press.

Robertson, A.

1984. People and the State: An Anthropology of Planned Development. Cambridge, UK: Cambridge University Press.

Rundstrom, R.

1995. "GIS, Indigenous Peoples, and Epistemological Diversity." Cartographic Geographic Information Systems 22: 45-57.

Ryavec, K.

1998. "Research Note: Regional Dynamics of Tibetan Population Change in Eastern Tibet, ca. 1940-1982." Population and Environment 20: 247-257.

Ryavec, K.

2001. "Land Use/Cover Change in Central Tibet, c. 1830-1990: Devising a GIS Methodology to Study a Historical Tibetan Land Decree." The Geographical Journal 167: 342-357.

Sapir, E.

1912. The Takelma Language of Southwestern Oregon. Washington: Government Printing Office.

Schlee, G. (Editor)

1989. Identities on the Move: Clanship and Pastoralism in Northern Kenya. Manchester: Manchester University Press for the International African Institute, London.

Scott, J.

1998. Seeing Like a State: How Certain Schemes to Improve the Human Condition Have Failed. New Haven: Yale University Press.

Scott, J.

1985. Weapons of the Weak: Everyday Forms of Peasant Resistance. New Haven: Yale University Press.

Shakabpa, T. W.

1967. Tibet: A Political History. New Haven: Yale University Press.

Sillitoe, P.

1998. "The Development of Indigenous Knowledge: A New Applied Anthropology." Current Anthropology 39: 223-252.

Sneath, D.

2000. Changing Inner Mongolia: Pastoral Mongolian Society and the Chinese State. Oxford: Oxford University Press.

Uebach, $\mathrm{H}$.

1994. "Small Units in the Territorial Division of the Tibetan Empire $\left(7^{\text {th }}-9^{\text {th }}\right.$ Century)." Proceedings of the International Association of Tibetan Studies VII 2: 997-1003.

Warhus, M.

1997. Another America: Native American Maps and the History of Our Land. New York: St. Martin's Press.

Watts, M.J.

1992. "Space for Everything (A Commentary)." Cultural Anthropology 7: 115-129.

Wylie, T.

1959. "A Standard System of Tibetan Transcription." Harvard Journal of Asiatic Studies 2: 261-267. 


\begin{abstract}
Spatial analysis can bring out crucial issues in the political ecology of pastoral areas, with important implications for planning future development. This research combines textual analysis, participatory mapping, ethnography, and remote sensing data to study resource use and common property among pastoralists in Central Tibet. Specifically, this paper presents a case study of pasture boundaries over time in the Porong region (Nyelam County, Shigatse Prefecture, Tibet Autonomous Region, PRC). Translation and analysis of an historical (1884) boundary survey from Porong yielded hundreds of toponyms, boundary markers, livestock corrals, and resource locations, which were catalogued and indexed in a geographical database. Toponyms and landscape features listed in the boundary survey were geo-referenced using a Geographic Positioning Systems (GPS) unit: fieldwork in Tibet resulted in the collection of over five hundred GPS points that marked historical and contemporary pasture boundaries. In addition, participatory maps of pastures were generated with local herders and subsequently digitized using Geographic Information Systems (GIS) software. These compiled GIS maps provide a time series of common property boundaries and illustrate how changes in Tibet's governance (feudalism vs. socialism) and type of economy (e.g., collectivized vs. private household production) did or did not impact the distribution of resources among pastoralists. Analysis of vegetation resources available within historical and contemporary common property units provides compelling evidence that boundaries reflect the balance of power relations, resulting in unequal availability of rangeland resources. The case study adds to the literature on common property by reinserting the state's central roles in defining boundaries, regulating resource use, and mediating resource conflicts.
\end{abstract}

Key Words: participatory mapping, GIS, Central Tibet, common property resource management. 